\title{
Seminal fluid transferrin as an index of gonadal function in men*
}

\author{
C. Barthelemy, B. Khalfoun $\dagger$, J. M. Guillaumin $\dagger$, P. Lecomte $\ddagger$ \\ and P. Bardos $\dagger$ \\ Laboratoire de Biologie de la Reproduction, CHU Bretonneau, 37044 Tours Cedex, $\uparrow$ Laboratoire \\ d'Immunologie, Faculté de Médecine, 37032 Tours Cedex; and $\ddagger$ Centre d'Etudes et de traitement \\ de la stérilité de Tours, CHU Bretonneau, 37044 Tours Cedex, France
}

\begin{abstract}
Summary. Seminal fluid transferrin concentrations of proven fertile donors and normozoospermic patients were significantly higher $(P<0.001)$ than those in other groups examined. There were no significant differences in the transferrin values among vasectomized, azoospermic and very severe oligozoospermic subjects. Values were also similar in patients affected by secretory or excretory azoospermia. Regression analysis showed a positive correlation $(P<0.001, r=0.72)$ between seminal fluid transferrin concentrations and sperm density. A negative correlation $(P<0.02, r=0.28)$ existed between circulating FSH and seminal fluid transferrin concentrations. There were no significant differences between seminal fluid transferrin and the percentages of abnormal sperm cells or immature seminal line elements. These results indicate that the nature of seminiferous tubule dysfunction can be precisely defined by examining seminal fluid transferrin in combination with other biological values usually used to explore testicular function.
\end{abstract}

\section{Introduction}

Male infertility remains poorly understood and eludes specific diagnosis (Parvinen, 1982; Sanborn et al., 1986). In the past few years, much work has been devoted to the identification of adequate markers for evaluating specific testicular cell function. Sertoli cells, one of the most important cell groups, may play a crucial role in spermatogenesis by creating a unique intratubule microenvironment and by secreting several components into the seminiferous tubule fluid. Among these, transferrin has been detected in the culture media of human and rat Sertoli cells, where its concentration accounted for about 5\% of newly synthesized proteins (Skinner \& Griswold, 1980; Holmes et al., 1984). Testicular transferrin production by cultured Sertoli cells is regulated by peptide and steroid hormones known to be related to spermatogenesis (Skinner \& Griswold, 1982; Perez-Infante et al., 1986). Iron plays an important role in cell growth by catalysing key reactions, in energy metabolism and in DNA synthesis (Hoffbrand et al., 1976). The glycoprotein transferrin is the major iron transporter and is therefore an essential growth factor (Aisen \& Listowsky, 1980). The function of transferrin in the testes is unknown, but it may participate in supplying iron to differentiating and developing germ cells. Specific transferrin receptors have been localized on the surface of late pachytene and round spermatids (Holmes et al., 1983). Quantitative studies of transferrin concentrations in the seminal fluid of clinically defined subjects have furnished data suggesting that seminal fluid transferrin values could be used as a reliable clinical index for determining the functional status of Sertoli cells or seminiferous tubules (Holmes et al., 1982; Sueldo et al., 1984; Orlando et al., 1985).

\footnotetext{
* Reprint requests to Professor P. Bardos.
} 
We have developed a method for assaying seminal fluid transferrin (Khalfoun et al., 1986). The present report is a further investigation of relationships between seminal fluid transferrin and other values known to be related to testicular function.

\section{Materials and Methods}

Patients. This study was carried out with semen collected from 11 proven fertile donors, 154 infertile men and 20 vasectomized patients ( 3 months after operation). The clinical definition and classification of the patients, based on sperm concentrations, are shown in Table 1.

Spermogram. Semen samples were taken from subjects by masturbation into sterile containers after at least 3 days of sexual abstinence. After liquefaction at $37^{\circ} \mathrm{C}$, the sample volume, $\mathrm{pH}$, motility and sperm counts were determined with standardized methods (World Health Organization recommended procedure, 1980). Polynuclear and round cells were estimated with the differential staining technique of Endtz (1972). Spermatozoa with abnormal morphology were identified and their percentage was evaluated with the classification method of David et al. (1975).

Identification of excretory and secretory azoospermic patients. FSH was systematically assayed in all total azoospermia patients and was complemented by a testicular biopsy if the concentration was normal. In addition excretory and secretory azoospermic patients were categorized by determining seminal fluid concentrations of L-carnitine base (Soufir, 1985), fructose (glucose-fructose kit: Boehringer, Mannheim Meylan, France) and acid phosphatase activity (acid phosphatase kit: Bio Mérieux, Charbonnières les Bains, France). After liquefaction semen samples were centrifuged at $1000 \mathrm{~g}$ for $10 \mathrm{~min}$ and supernatants were stored in liquid nitrogen until assayed.

Transferrin assay. Human transferrin in seminal fluid or serum was assayed by the technique we have described elsewhere (Khalfoun et al., 1986). Briefly, the radioimmunoassay (RIA), used antibody-coated polystyrene tubes as the solid phase. The assay range was 4 to $800 \mathrm{ng} / \mathrm{ml}$ and the logit-log plot was linear with a regression coefficient of $r=0.99$. Results are expressed in $\mu \mathrm{g} / \mathrm{ml}$ seminal fluid and $\mu \mathrm{g} /$ total volume of ejaculate in the study of the correlation with FSH in order to eliminate variations due to the dilution effect by seminal fluid.

Assaying human follicle stimulating hormone (FSH). FSH was assayed in the serum of subjects with an RIA kit (IRE FSH-RIA, Fleurus, Belgium) using the international MRC standard 78/549. The percentages of cross-reaction are respectively: $\mathrm{hCG}=0 \%, \mathrm{LH}=0.2 \%, \mathrm{TSH}=1 \%$. The minimal detectable dose of FSH is: $0.26 \pm 0.03 \mathrm{ng} / \mathrm{ml}$ (mean \pm s.d.).

Statistical analysis. Data were compared with Student's $t$ test. Correlation coefficients were determined among seminal fuid transferrin concentrations, sperm counts and serum FSH concentration.

\section{Results}

\section{Patient classifications}

Table 1 summarizes the classification of the infertile patients, who were considered to be azoospermic, oligozoospermic or normozoospermic. Azoospermic patients were subdivided into excretory and secretory types, depending on seminal fluid concentrations of L-carnitine base, fructose and acid phosphatase. As a function of sperm concentration, the normozoospermic group was subdivided into subgroups NI, NII and NIII, and the oligozoospermic group into three subgroups of very severe, severe and moderately oligozoospermic. Two control groups were included for the sake of comparison: vasectomized patients and proven fertile donors.

\section{Transferrin concentrations in seminal fluid}

As shown in Table 2, the transferrin concentration in the semen of the normozoospermic NIII subgroup or proven fertile donors was significantly higher $(P<0.001)$ than in the samples of the other groups, especially vasectomized patients. There were no significant differences in seminal fluid transferrin concentrations (i) among vasectomized, secretory azoospermic, excretory azoospermic and very severe oligozoospermic patients; (ii) between secretory and excretory azoospermic patients, (iii) among normozoospermic NII, NIII subjects and proven fertile donors. There were significant differences in normozoospermic subjects (NI $<$ NII and NIII) and oligozoospermic patients (very severe $<$ severe $<$ moderate). 
Table 1. Definition and classification of patients as a function of sperm density and seminal fluid transferrin concentrations

\begin{tabular}{|c|c|c|c|c|}
\hline \multirow[b]{2}{*}{$\begin{array}{l}\text { Patient } \\
\text { definitions }\end{array}$} & \multirow{2}{*}{$\begin{array}{c}\text { No. } \\
\text { of } \\
\text { men }\end{array}$} & \multicolumn{2}{|c|}{ Sperm count $\times 10^{-6}$} & \multirow[b]{2}{*}{$\begin{array}{l}\text { Transferrin conc. } \\
(\mu \mathrm{g} / \mathrm{ml} \text { seminal plasma }\end{array}$} \\
\hline & & $\begin{array}{l}\text { Per ml of } \\
\text { seminal fluid }\end{array}$ & $\begin{array}{l}\text { Per total volume } \\
\text { of ejaculate }\end{array}$ & \\
\hline Post-vasectomy $(\mathrm{P})$ & 20 & 0 & 0 & $17.30^{\mathrm{a}} \pm 7.49$ \\
\hline Secretory azoospermia (SA) & 17 & 0 & 0 & $19.93^{\mathrm{a}} \pm 9.12$ \\
\hline Excretory azoospermia (EA) & 8 & 0 & 0 & $17.52^{\mathrm{a}} \pm 10 \cdot 49$ \\
\hline Very severe oligozoospermia (VSO) & 17 & $<1$ & $<2$ & $23.78^{\mathrm{a}} \pm 7.19$ \\
\hline Severe oligozoospermia (SO) & 17 & $1-10$ & $2-20$ & $30 \cdot 85^{b} \pm 12 \cdot 13$ \\
\hline Moderate oligozoospermia (MO) & 25 & $10-20$ & $20-80$ & $42 \cdot 11^{\circ} \pm 18 \cdot 65$ \\
\hline Normozoospermia $(\mathrm{N})$ : I & 26 & $20-80$ & $80-200$ & $61 \cdot 45^{\mathrm{d}} \pm 20 \cdot 38$ \\
\hline Normozoospermia (N): II & 28 & $80-120$ & $200-400$ & $71.75 \pm 23.55$ \\
\hline Normozoospermia (N): III & 16 & $>120$ & $>400$ & $93.97 \pm 32.08$ \\
\hline Proven fertile donors (PFD) & 11 & $>120$ & $>400$ & $92 \cdot 12 \pm 25 \cdot 94$ \\
\hline
\end{tabular}

Values are means \pm s.d.

${ }^{2} P<0.001$ compared respectively with SO, MO, NI, NII, NIII, PFD.

${ }^{\mathrm{b}} P<0.05$ compared with MO, $P<0.001$ compared with NII, NIII, PFD.

' $P<0.01$ compared with NI, $P<0.001$ compared with NII, NIII, PFD.

${ }^{d} P<0.05$ compared with NII, $P<0.001$ compared with NIII and PFD.

Table 2. Relationships between seminal plasma transferrin concentrations and spermatozoa with abnormal morphological features

\begin{tabular}{cccc}
\hline $\begin{array}{c}\text { Sperm conc./ } \\
\mathrm{ml} \times 10^{-6}\end{array}$ & $\begin{array}{c}\text { No. of } \\
\text { men }\end{array}$ & $\begin{array}{c}\text { \% abnormal } \\
\text { spermatozoa }\end{array}$ & $\begin{array}{c}\text { Transferrin conc. } \\
(\mu \mathrm{g} / \mathrm{ml} \text { seminal fluid })\end{array}$ \\
\hline $20-80$ & 13 & $>50$ & $59 \cdot 67 \pm 20 \cdot 8$ \\
& 13 & $\leq 50$ & $65 \cdot 98 \pm 19 \cdot 3$ \\
$80-120$ & 16 & $>50$ & $85 \cdot 68 \pm 24$ \\
& 12 & $\leq 50$ & $79 \cdot 11 \pm 32 \cdot 59$ \\
$\geq 200$ & 17 & $>50$ & $93.97 \pm 32.08$ \\
& 10 & $\leq 50$ & $93.12 \pm 25.94$ \\
\hline
\end{tabular}

Values are mean \pm s.d.

\section{Correlations between seminal fluid transferrin concentrations and other values}

Sperm counts. Figure 1 shows that variations of seminal fluid transferrin were a linear function $(y=0.36 x+30 \cdot 12)$ of sperm count, with a regression coefficient of $r=0.72(P<0.001)$.

Serum FSH. Among the 74 subjects whose circulating FSH was assayed, there were 23 cases of elevated FSH $(>8.85 \mathrm{mIU} / \mathrm{ml})$. These subjects with high FSH had a significantly lower seminal fluid transferrin level $(52.4 \pm 25.6 \mu \mathrm{g}$ /ejaculate) than those with low serum FSH $(71.6 \pm 33.4 \mu \mathrm{g} /$ ejaculate). Figure 2 shows a positive correlation between circulating FSH concentrations and seminal fluid transferrin levels $(r=0.445, P<0.002)$. The variations between serum FSH concentrations and seminal fluid transferrin levels were a curvilinear function $\left(y=8.04 \times 10^{-5} x^{2}-\right.$ $0.07 x+14.63)$. The quality of the correlation is inferior if transferrin is expressed in $\mu \mathrm{g} / \mathrm{ml}$, as a result of individual variability of ejaculate volume.

Percentage of spermatozoa with abnormal morphology. The semen of oligozoospermic subjects contained a high proportion $>50 \%$ ) of spermatozoa with abnormal morphological features. Therefore, this study was conducted only in patients with a sperm density $\geq 20 \times 10^{6} / \mathrm{ml}$ (Table 3). Statistical analyses showed the absence of any significant difference in seminal fluid transferrin concentrations between patients with high $(>50 \%)$ or low $(\leq 50 \%)$ percentages of spermatozoa with abnormal morphology. 


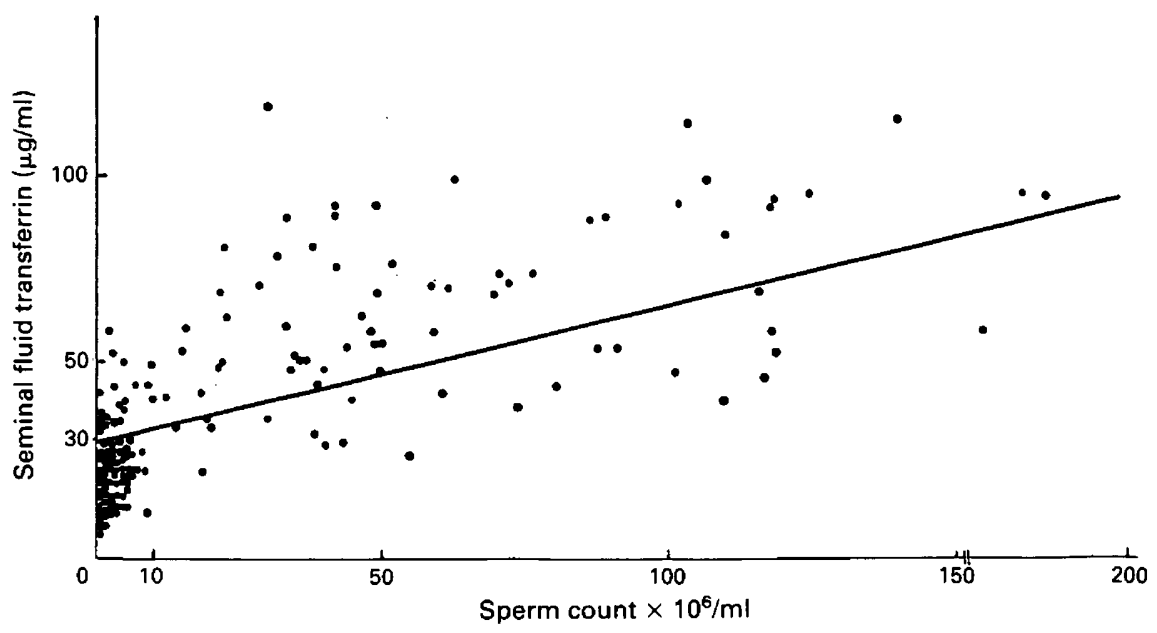

Fig. 1. Correlation between seminal fluid transferrin concentrations and sperm count.

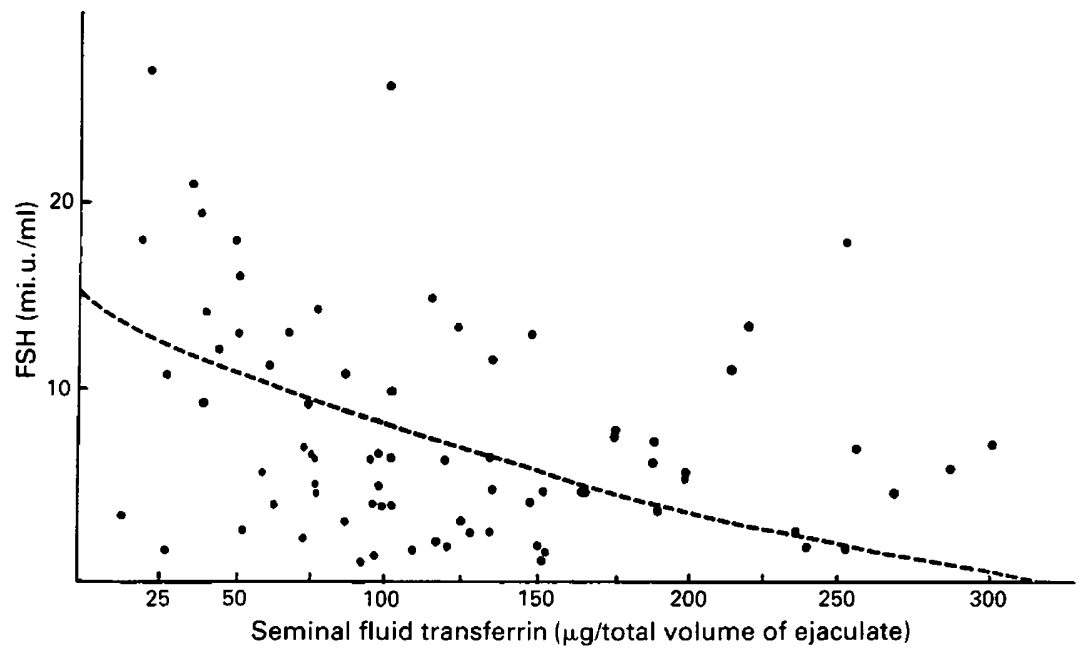

Fig. 2. Correlation between follicle-stimulating hormone (FSH) concentration and seminal plasma transferrin concentration.

Table 3. Relationships between seminal plasma transferrin concentrations and immature seminal elements

\begin{tabular}{cccc}
\hline $\begin{array}{c}\text { Sperm conc. } \\
\times 10^{-6}\end{array}$ & $\begin{array}{c}\text { No. of } \\
\text { men }\end{array}$ & $\begin{array}{c}\% \text { immature } \\
\text { seminal elements }\end{array}$ & $\begin{array}{c}\text { Transferrin conc. } \\
(\mu \mathrm{g} / \mathrm{ml} \text { seminal fluid })\end{array}$ \\
\hline$\leq 1$ & 9 & $>50$ & $21.9 \pm 6.73$ \\
& 8 & $\leq 50$ & $24.2 \pm 7.29$ \\
$1-10$ & 8 & $>50$ & $34.06 \pm 11.99$ \\
& 9 & $<50$ & $30.63 \pm 11.76$ \\
$20-80$ & 11 & $>10$ & $70 \cdot 7 \pm 20.65$ \\
& 15 & $\leq 10$ & $58.58 \pm 19.75$ \\
\hline
\end{tabular}

Values are mean \pm s.d. 
Percentage of immature elements in the seminal line. Table 4 shows the results of seminal fluid transferrin concentrations as a function of the percentages of immature seminal line cells. There were no significant differences between subjects with a high $(>10 \%$ or $>50 \%)$ and low $(\leq 10 \%$ or $\leq 50 \%$ ) percentage of immature seminal line elements.

\section{Discussion}

The present study examined the relationships between seminal fluid transferrin and some biological measurements used as an index of testicular function. The transferrin concentrations encountered were of the same order as those reported by Holmes et al. (1982) and Foresta et al. (1986), carried out on similar populations. Other workers (Orlando et al., 1985; Chan et al., 1986), however, found lower values in comparable populations. Our results showed that transferrin concentrations in vasectomized patients were significantly lower (about 5 times) than in normozoospermic men or proven fertile donors. This difference suggests that the major source of seminal fluid transferrin is testicular, as had been previously suggested (Holmes et al., 1982). The remainder of the transferrin may originate from secretion by the prostate and/or seminal vesicles and/or serum transudation. The lack of a correlation between blood and seminal transferrin $(y=30+3 \cdot 36 x, r=0 \cdot 29)$ nevertheless suggests a low participation by the serum component.

Seminal fluid transferrin concentrations were positively correlated with sperm density, confirming earlier findings (Holmes et al., 1982; Orlando et al., 1985; Foresta et al., 1986). Although the interpretation of this correlation is difficult, the seminal fluid transferrin concentration reached relatively stable values once sperm density exceeded $120 \times 10^{6}$ spermatozoa $/ \mathrm{ml}$. The concentration of transferrin $(\simeq 90 \mu \mathrm{g} / \mathrm{ml})$ at this threshold value could represent the optimum concentration for obtaining good quality spermatogenesis. Transferrin concentrations in azoospermia and very severe oligozoospermia $\left(\leqslant 1 \times 10^{6}\right.$ spermatozoa $\left./ \mathrm{ml}\right)$ were identical and significantly lower than those in the other groups, but did not lead to the distinction between excretory and secretory azoospermic patients, agreeing with published findings (Orlando et al., 1985; Chan et al., 1986). There was no significant difference in the transferrin concentration between the normal group and that with considerable abnormal morphological features or that with a high percentage of immature seminal line elements. These results are more in favour of transferrin playing a role in quantitative aspects of spermatogenesis (number of gametes produced) than in qualitative aspects (production of abnormal cells). This hypothesis is supported by the fact that transferrin receptors have been localized on the surface of spermatids in early stages of development (Holmes et al., 1983; Sylvester \& Griswold, 1984). The interaction of transferrin with its receptor is known to be essential in the cell proliferation process (Dautry-Varsat et al., 1983).

The quantitative assays of transferrin in the seminal fluid of clinically defined subjects suggests that seminal fluid transferrin could be used as a reliable clinical index of the functional status of Sertoli cells or seminiferous tubules (Holmes et al., 1982; Orlando et al., 1985). Furthermore, deterioration in spermatogenesis has classically been related to increases in serum FSH (de Kretser et al., 1972). We found an inverse relationship between serum FSH and seminal fluid transferrin, in contrast to some published reports (Sueldo et al., 1984; Orlando et al., 1985; Chan et al., 1986) and in agreement with others (Holmes et al., 1982). We also found that seminal fluid transferrin concentrations were significantly lower in azoospermic or severe oligozoospermic men with high FSH compared to those with low FSH. This tends to indicate that the two measures are correlated and reliable in evaluating an azoospermia or an oligozoospermia. Nevertheless, some workers have reported cases of azoospermia with normal FSH (de Kretser et al., 1972; Mansat et al., 1986) and we found decreased transferrin concentrations in azoospermic subjects with severe histological lesions and normal FSH. These facts favour the hypothesis that transferrin is a direct index of the functional state of Sertoli cells and seminiferous tubules to a greater extent than FSH, which is only an indirect index via inhibin secretion by Sertoli cells (Franchimont et al., 1972; Steinberger \& Steinberger, 1976). 
In conclusion, the measurement of seminal fluid transferrin is a non-invasive and non-traumatic examination which seems to be indispensable in the investigation of azoospermias and oligozoospermias, as a complement to serum FSH assays and the other biological values usually examined in this context.

This work was supported by INSERM grant No. 1270 02, the Langlois Foundation, the ARC and the MEN Research Direction. We thank Professor Besnard, Dr M. Lanson and Dr Schramme for their help and co-operation and P. Galmard for preparation of the manuscript.

\section{References}

Aisen, P. \& Listowsky, I. (1980) Iron transport and storage proteins. Ann. Rev. Biochem. 49, 357-398.

Chan, S.Y.W., Loh, T.T., Wang, C. \& Tang, L.C.H. (1986) Seminal plasma Transferrin and seminiferous tubular dysfunction. Fert. Steril. 45, 687-691.

Dautry-Varsat, A., Clechanover, A. \& Lodish, H.F. (1983) $\mathrm{pH}$ and the recycling of transferrin during receptor-mediated endocytosis. Proc. natn. Acad. Sci. U.S.A. 80, 2258-2262.

David, G., Bisson, J.P., Czyglik, F., Jouannet, P. \& Gernigon, C. (1975) Anomalies morphologiques du spermatozoide humain. I: proposition pour un système de classification. J. Gynecol. Obstet. Biol. Reprod. 4, 17-36.

de Kretser, D.M., Burger, H.G., Fortune, D., Hudson, B., Long, A.R., Paulsen, C.A. \& Taft, H.P. (1972) Hormonal, histological and chromosomal studies in adult males with testicular disorders. J. clin Endocr. Metab. 35, 392-401.

Endtz, A.W. (1972) Een methode om het voditige urine sediment en het vochtige menselyke sperma rechtstreeks te keuren. Ned. Tydschr. Generskd 117, 681-692.

Foresta, C., Mansoni, F., Businaro, V., Donabel, C., Mariangela, I. \& Scandellari, C. (1986) Possible significance of transferrin levels in seminal plasma of fertile and infertile men. $J$. Androl. 77, 77-82.

Franchimont, P., Millet, D., Vendrely, E., Letane, J., Legros, J.J. \& Netter, A. (1972) Relationship between spermatogenesis and serum gonadotropin levels in azoospermia and oligozoospermia. J. clin. Endocr. Metab. 34, 1003-1038.

Hofibrand, A.V., Ganeshaguru, K., Hooton, J.W.R. \& Tattersall, M.N. (1976) Effect of iron deficiency and desferrioxamine on DNA synthesis in human cells. Br. J. Haematol. 33, 517-525.

Holmes, S.D., Lipshultz, L.I. \& Smith, R.G. (1982) Transferrin and gonadal dysfunction in man. Fert. Steril. 38, 600-604.

Holmes, S.D., Bucci, L.R., Lipshultz, L.I. \& Smith, R.G. (1983) Transferrin binds sepcifically to pachytene spermatocytes. Endocrinology 113, 1916-1918.

Holmes, S.D., Lipshultz, L.I. \& Smith, R.G. (1984) Regulation of transferrin secretion by human sertoli cells cultured in the presence or absence of human peritubular cells. J. clin. Endocr. Metab. 59, 1058-1062.

Khalfoun, B., Barthelemy, C., Crouzat-Reyenes, G. \& Bardos, P. (1986) A simple and sensitive solid phase radioimmunoassay for measuring the transferrin contents of human biological fluids: its application to seminal plasma. Int. J. Biochem. 18, 1135-1139.
Mansat, A., Pontonnier, F., Malonga, G., Mieusset, R. (1986) Biopsies testiculaires dans les azoospermies explorées et/ou traitées chirurgicalement. Contracep. Fert. Sex. 14, 39-42.

Orlando, C., Caldini, A.L., Barni, T., Wood, W.G., Straburger, C.J., Natali, A., Mauer, A., Forti, G. \& Serlo, M. (1985) Ceruloplasmin and transferrin in human seminal plasma: are they an index of seminiferous tubular function? Fert. Steril. 43, 290-294.

Parvinen, M. (1982) Regulation of the seminiferous epithelium. Endocr. Reviews 3, 404-417.

Perez-Infante, V., Bardin, C.W., Gunsalus, G.L., Musto, N.A., Rich, K.A. \& Mather, J.P. (1986) Differential regulation of testicular transferrin and androgen binding protein secretion in primary cultures of rat Sertoli cells. Endocrinology 118, 382-392.

Sanborn, B.M., Wagle, J.R., Steinberger, A. \& Greer Emmert, D. (1986) Maturational and hormonal influences on sertoli cell function. Endocrinology 118, 1700-1709.

Skinner, M.K. \& Griswold, M.D. (1980) Sertoli cells secrete transferrin like protein. J. biol. Chem. 225, 9523-9525.

Skinner, M.K. \& Griswold, M.D. (1982) Secretion of testicular transferrin by cultured sertoli cells is regulated by hormones and retinoids. Biol. Reprod. 27, $21 \mathrm{I}-221$.

Soufir, J.C. (1985) Azoospermie, asthénozoospermie et biochimie séminale. Annls Biol. Clin. 43, 67-70.

Steinberger, A. \& Steinberger, E. (1976) Secretion of an FSH inhibiting factor by cultured sertoli cells. Endocrinology 99, 918-921.

Sueldo, M.D., Marrs, R.P., Berger, J., Kletzky, D.A. \& O'Brien, T.J. (1984) Correlation of semen transferrin concentration and sperm fertilizing capacity. Am. J. Obstet. Gynecol. 150, 528-531.

Sylvester, S.R. \& Griswold, M.D. (1984) Localization of transferrin and transferrin receptors in rat testis. Biol. Reprod. 31, 195-203.

World Health Organization (1980) Laboratory manual for the examination of human semen and semen cervical mucus interaction. Eds M. A. Belsey, R. Eliasson, A. J. Gallegos, K. S. Moghissi, C. A. Paulsen \& M. R. N. Prasad. Press Concern, Singapore. 